\title{
A Research Framework for Antecedents to Interpersonal Trust Development from Organizational Perspective
}

\author{
Muhammad Abdul Basit-Memon ${ }^{1 *}$, Manzoor Ali Mirani' ${ }^{1}$, Shahid Bashir ${ }^{2}$
}

\begin{abstract}
The researchers from a number of fields and disciplines have analyzed the role of trust as one of the most significant factors affecting the organizational performance. Trust facilitates and moderates the impact of other variables on employee-performance or organizational behavior; since it builds up the grounds over which the foundation of certain expected outcomes and results can be laid on. Due to increasing importance of trust, there has been a rigorous focus of researchers, academicians and practitioners to identify the antecedents to trust i.e. the factors that increase or decrease the extent of trust in organizational settings. This paper presents a research framework of the antecedents to interpersonal trust development from an organizational perspective, in the light of the existing literature and available empirical evidence to help the researchers, academicians and practitioners to identify the determinants of interpersonal trust development. We believe that the constructs identified in this paper will help the researchers to develop the models of trust building and provide guidelines for meaningful and valuable research in future in the domain of trust development.
\end{abstract}

Keywords: Trust, Commitment, Religiosity, Shared Values, Organizational justice.

\section{Introduction}

Trust is one of the constructs that have achieved wide recognition from scholars and academicians from all over the world across fields and disciplines ranging from organizational behavior Zaheer, McEvily, and Perrone (1998); strategic management Barney and Hansen (1994); social psychology Lewicki and Bunker (1996) to economics Williamson (1993) and international business (Inkpen \& Currall, 1997). This is perhaps because trust provides the foundation for any productive and successful interpersonal and professional relationship among individuals and organizations (Mayer, Davis, \& Schoorman, 1995). Many scholars e.g. (Zak \& Knack, 2001) believe that a nation's economic progress and global business growth is highly influenced by the extent of trust. Moreover, trust provides the basis for all human systems of ethics and morality Buchan, Croson, and Dawes (2002) and according to Putnam (2001), it is the very foundation of society and civilization and key to human progress in almost https://doi.org/10.30537/sijmb.v4i1.106

${ }^{1}$ Department of Business Administration, Sukkur IBA University, Sindh Pakistan

* Corresponding Author: basit.memon@iba-suk.edu.pk

${ }^{2}$ School of Business \& Economics, University of Management \& Technology, Sialkot Campus SIJMB | E-ISSN: 2410-1885; P-ISSN: 2313-1217 @ 2017 Sukkur IBA University - All Rights Reserved 
every walk of life. This is why Arrow (1974) calls trust "important lubricant for human society".

Researchers on trust have highlighted the importance of trust in numerous dimensions: for instance, it can increase the satisfaction level of employees, performance and problem-solving capability (Butler Jr (1999); Zand, 1972), can improve communication and enhance job commitment (Mayer \& Gavin, 2005) and can create citizenship behavior (Akbar, 2010). It can also improve team performance Dirks (2000), knowledge sharing Levin and Cross (2004), manager subordinate working relationships and organizational ability to take on to complexity and volatility of the business environment (Kramer, 1999). To achieve competitive advantage, organizations need to have resources that are rare, valuable and inimitable. So is the case of trust, which is a very important source for organizations to achieve competitive advantage Bashyakar (2010). Since it is rare, valuable and cannot be imitated by other organizations, from an inter-organizational perspective, trust plays the role of cost reducing and value enhancing factor through more productive and effective collaboration and sharing of information within the organizations Madhok (2006) and paving way for expanding a number of potential business associates (Zaheer et al., 1998). From intra-organizational perspective, the extant literature posits a positive association between trust and collaborative working, within various organizational units, departments and divisions. While investigating the antecedents of organizational cooperation, Smith, Carroll, and Ashford (1995) found trust as a cardinal factor for ensuring cooperation within various units of organizations. Subsequently, Dirks and Ferrin (2002) after investigating the impact of trust on organizational functioning, in the light of existing literature, conceptualized trust as directly or indirectly influencing factor on a number of organizational performance and behavior oriented outcomes. They argue that trust facilitates and moderates the impact of other variables on employee-performance or organizational behavior; since it builds up the grounds over which the foundation of certain expected outcomes and results can be laid on. In another effort to analyze the influence of trust in organizational settings, McEvily, Perrone, and Zaheer (2003) portray trust as a fundamental element for ensuring coordination to perform various organizational activities.

\section{Conceptualization of Trust}

In the view of Brewer and Brown (1998) trust is "a psychological state comprising the intention to accept vulnerability based upon positive expectations of the intentions or behavior of another". In other words, it can be said that trust is the willingness of a person to be defenseless to others, with the assumption that other fellows are trustworthy (Schoorman, Mayer, \& Davis, 2007). Reliance and risk tend to be interlinked with trust. Reliance shows one person's willingness to let his fate be decided by the other. Risk involves that one party can potentially experience negative outcome, due to untrustworthy and unprincipled behavior of the second party. Trust is

Sukkur IBA Journal of Management and Business | Volume 4 No. 1 January - June 2017 @ Sukkur IBA University 
irrelevant without risk, since there is no vulnerability without risk (Luo, 2002). Trust has two dimensions: calculative and relational (Inkpen \& Currall, 1997). Calculative trust which is also named as cognitive trust tends to be short-run oriented trust, based on the hope or belief of one person that the other will act in a beneficial and positive way. On the contrary, relational or affective trust builds as a result of recurrent connections between two parties over a period of time. Affect-based or relational trust tends to be a long-run oriented trust, based on a feeling of emotional attachment, which develops after frequent interactions between the two parties; since repeated interactions lead to the cultivation of passionate bond based on reciprocal care and concern (McAllister, 1995).

Generally, individuals base their trust on others through their observations of certain features/qualities of the individuals. Researchers have identified a number of variables to be used for the evaluation of trustworthiness e.g. integrity, competence, openness, discreetness and receptivity etc. Butler Jr (1999), but, they can be precisely grouped into three categories: perceptions of the trustee in the "ability or competence", "benevolence", and "integrity" of the trustee (Mayer et al., 1995).

\section{Antecedents to Interpersonal Trust Development}

Despite growing focus of researchers on the study of antecedents to trust development, a lot of work needs to be done Katinka and Paul (2003) in this field, keeping in view the increasing benefits of interpersonal and organizational trust. Because the study of trust in the existing literature is not free of problems and issues due to some inconsistencies and variations in the way trust has been defined and conceptualized by the researchers (Dirks \& Ferrin, 2002). A notable criticism from some scholars in this connection refers to the absence of convergence on the nature and structure of trust, particularly with respect to the inability of the researchers and academicians to differentiate between the very constructs and antecedents of trust (Mayer et al., 1995). The researchers seem to overlap the basic constructs/facets or underlying assumptions of trust with antecedents to trust. For instance, according to Costa (2001) trust is a multi-dimensional construct consisting of three interrelated facets including perceived trustworthiness, propensity to trust and monitoring of behaviors, whereas propensity to trust, according to Gill, Boies, Finegan, and McNally (2005) more accurately, might be conceptualized as an antecedent to trust instead of a dimension of the same. On the other side, trustworthiness has also been discussed as an antecedent to trust development instead of a dimension (Lewicki \& Bunker, 1996)

Moreover, most of the studies in the domain of antecedents to trust are focused on different dimensions of organizational trust. For example, antecedents to organizational trust Gulati (1995), antecedents of trust in managers Katinka and Paul (2003), antecedents to trust in virtual communities Ridings, Gefen, and Arinze (2002) antecedents to inter-organizational trust Gill et al. (2005); just to mention a few.

Sukkur IBA Journal of Management and Business | Volume 4 No. 1 January - June 2017 @ Sukkur IBA University 
However, there is limited number of studies focusing on antecedents to interpersonal trust. Literature about the antecedents to interpersonal trust covers a big list of antecedents including for example: commitment (Butler Jr, 1999); loyalty (H. H. Tan \& Chee, 2005); confidentiality (Butler Jr, 1999; H. H. Tan \& Chee, 2005), dependability (Rempel, Holmes, \& Zanna, 1985); reliability (H. H. Tan \& Chee, 2005); responsibility (Butler Jr, 1999), affect (Lewicki \& Bunker, 1996); group similarity (Brewer \& Brown, 1998); propensity to trust (Rempel et al., 1985), reciprocity (Wasti, Tan, \& Erdil, 2011) and shared values (Cazier, Shao, \& Louis, 2006) etc. However, it is more appropriate to discuss the antecedents that are more relevant to the current study which focuses on the development of interpersonal trust within organizations among organizational members.

\section{a. Trustworthiness}

Trust development refers to individuals' experiential process of knowing about others' level of trustworthiness, based on the interaction with them over a period of time (Mayer et al., 1995). Numerous researchers have proposed trustworthiness as a strong factor influencing trust development (e.g. (Lewicki \& Bunker, 1996); (McAllister, 1995)). Mayer et al. (1995), posit perceived trustworthiness as an important cognitive antecedent of trust. Researchers from multiple disciplines concur that people develop trust because of repeated social interactions, which help them in updating their information about the level of trustworthiness of others (e.g. (Zand, 1972); (Mayer et al., 1995)). Previous research on trust from organizational perspective, suggests competency and responsibility as fundamental elements for trustworthiness (Butler Jr, 1999). Dependability and reliability have also been included in the list of the antecedents of interpersonal trust (Rempel et al., 1985). Expectations of dependability and reliability need to be met for cultivating and prospering trust based relationships Zucker (1986) and lack of the same provides a rational ground for ending up trustbased relationship (Luhmann, 1979). Researchers have identified as many as ten facets of perceived trustworthiness; including dependability, reliability, responsibility and predictability etc. (Butler Jr, 1999; Mishra, 1996). However, three antecedents to trust development have received the attention of maximum number of scholars and researchers in the literature of trust development: "benevolence", "ability" and "integrity" (Hardin, 2002; Mayer et al., 1995; McAllister, 1995).

Benevolence, includes feelings of kindness, goodwill, magnanimity and compassion of trustor towards trustee (Mayer et al., 1995). According to Hardin (2002) and Das and Teng (1998), benevolence can be referred to as the product of goal congruence or common objectives, or the confidence achieved from the commonality of interests. Others have linked benevolence to the extent to which one party is sincere in safeguarding the welfare and well-being of the other party to achieve maximum collective benefits (Rempel et al., 1985). Benevolence is akin to McAllister (1995) conceptualization of affect-based trust, which results from the feelings of deep care and concern of one party toward the other.

Sukkur IBA Journal of Management and Business | Volume 4 No. 1 January - June 2017 @ Sukkur IBA University 
Ability refers to the faith of trustor in the trustee that he or she has the capability and resources to undertake a particular duty or perform a certain task (Butler Jr, 1999). Regardless of the spirit and hardworking of a person, the possibility of success is little and trust is not guaranteed, if that person is not capable of accomplishing that task or duty. Ability is parallel to McAllister (1995) conceptualization of peer dependability and reliability, which refers to the capability of trustee to commit, deliver and perform as per the expectation and promise.

Integrity means the perceived honesty and moral strength of trustee. Trustees having integrity are perceived to be more likely to dispose in fair and honorable manner with respect to their fulfilment of commitments and promises without cheating or manipulating. Thus, individuals are likely to build trust on those who possess integrity and commitment (Zolin, Hinds, Fruchter, \& Levitt, 2004).

\section{b. Propensity to Trust}

Propensity to trust indicates individuals' tendency of being optimistic or pessimistic towards people's actions and behaviors (DeNeve \& Cooper, 1998). People with high propensity to trust, possess positive intentions about other fellow-beings and think that others are good, fair, sincere and trustworthy, whereas people keeping low propensity to trust possess negative feelings about others and feel that others are unfair, selfish and untrustworthy (Shaw, 2001). Mayer et al. (1995), note that the propensity to trust is a very important indicator of one's trustworthiness, since different people tend to exhibit different levels of propensity to trust due to various environmental and cultural influences on their personalities. Propensity to trust, beyond interpersonal relationship, has been a significant factor in a variety of collectively desirable social activities such as car-pooling, commuting and public transportation (Van Lange et al., 1997). Propensity to trust is also influenced by individuals' approach to trust someone or not. Knowing the characteristics of both trustor and trustee helps understand the relationship between the two and the underlying reasons or logic to trust.

\section{c. Affect}

Numerous researchers from the fields of organizational theory, psychology and sociology, have emphasized affect as one of the crucial factors influencing trust e.g. (Lewicki \& Bunker, 1996). These scholars argue that affective connections take the shape of care, sincerity and benevolence that cultivate trust McAllister (1995), whereas emotional responses of individuals (e.g., happiness, fury, silence or frustration), gauge their feelings and levels of trust for others. Researchers, conceptualizing trust development as a "discrete process" composed of multiple stages, posit affect as a very powerful factor for cultivating higher and deeper levels of trust e.g. (Lewicki \& Bunker, 1996). Usually, trust built on affect, tends to be stronger and unshakeable over time, across favorable or unfavorable situations and even after small misunderstandings and violations (McAllister, 1995). For example, Rempel et al. (1985), suggest that 'faith' which tends to be the deepest level of trust, needs a truthful relationship, emotional

Sukkur IBA Journal of Management and Business | Volume 4 No. 1 January - June 2017 @ Sukkur IBA University 
attachment or affective investment of care and concern. Similarly, trust based on 'care and concern' tends to be deeper and long lasting and the one built on cognitive feelings of reliability, predictability and dependability (McAllister, 1995).

\section{d. Social Group Membership}

Social group affiliation is an important antecedent of trust development. People generally possess positive perceptions and feelings for the group. They tend to be associated with Brewer (1979), irrespective of their good or bad feelings, thoughts and beliefs about other groups. Two aspects affect trust-related views of individuals for other groups: first, people's own group memberships Turner, Hogg, Oakes, Reicher, and Wetherell (1987) and second, the interdependence that occurs between groups e.g. (Brewer \& Brown, 1998). Group interdependence is suggested as an important factor of feelings and belies for other groups. Self-categorization and social categorization Turner et al. (1987) are the fundamental psychological processes, which influence trust development with respect to group membership. Social categorization denotes the process of grouping or ungrouping of individuals based on age, gender, profession, community or ethnicity (Turner et al., 1987). Trust development tends to be heavily influenced by social categorization through category-driven mechanism, a cognitive process that provides a shortcut to individuals to decide which group to trust and which not; which people to rely on and which not (Hilton \& Von Hippel, 1996). Categorization or grouping is a kind of default mechanism that can help an individual to decide about building up trust when he or she feels confused whether to trust or not due to pressure of time or judgment issue. For example, "when an individual is distracted or attending to cues in the situation other than group membership, behaviors reflecting aversion or fear of out-group members are more likely to appear" (Brewer \& Brown, 1998).

In-group and out-group phenomenon is important in the current discussion. The group to which people belong is called an in-group and the group which is viewed in comparison to that group is called out-group. Individuals making contrasts with and making judgments about other groups usually try to keep positive depiction of their group Tajfel and Turner (1986) which actually contributes toward upholding their selfesteem (Turner et al., 1987). Based on the social identity theory, extant literature suggests that individuals' positive feelings about their group or group members, influence trust building and cooperation (Kramer, 1999). For instance, a sense of assistance increases in social dilemma experiments when an employee for example, comes to know about common identity of a person he works with (Kramer \& Brewer, 1984). Moreover, in-group and out-group phenomenon leads the individuals to prefer members belonging to their group and to think of them as relatively more cooperative, fair and trustworthy than those who are external to their group (Brewer, 1979). Moreover, group identity develops a sense of keeping group goals ahead of individual goals or aspirations and infuses a sense of similarity between individual and group goals (Kramer \& Brewer, 1984). When group members feel commonality of goals and aspirations, they start believing that other members will be enthusiastic in pursuing the

Sukkur IBA Journal of Management and Business | Volume 4 No. 1 January - June 2017 @ Sukkur IBA University 
group goals and will act in accordance with group values to achieve the goals and this will pave foundation for the cultivation of trust (Williams, 2001).

\section{e. Reciprocity}

Reciprocity, which refers to trustee's interchange of trustor's trusting behaviors such as entrustment and reliance, is one of the major antecedents to trust (Wasti et al., 2011). Observation over the ages tells that reciprocity leads to higher extent of trust (Zand, 1972). Despite the presence of some noteworthy contributions in connection to trust and reciprocity, Schoorman et al. (2007) note that the impact of such reciprocity on trust building needs to be studied with more number of studies, since it has not been plainly examined previously. Among the existing studies, for example, (Brewer \& Brown, 1998) noted that the level of trust in manager became higher when there was strong trust towards subordinates by the manager. Findings of Wasti et al. (2011) further strengthen the influence of reciprocity in building trust-based relations. Berg, Dickhaut, and McCabe (1995), in their study of trust and reciprocity in investment related decisions, found direct correlation of trust and reciprocity; suggesting reciprocity as one of the fundamental human attributes for building up trust. Based on their study, they further argued that the combination of trust and reciprocity for rational decision-making paradigm could allow better analysis of economic institutions, especially for framing and implementing joint decisions. The findings of Berg et al. (1995) concord with those of (Geanakoplos, Pearce, \& Stacchetti, 1989). However, Schoorman et al. (2007) in their integrative model of trust, have not suggested a direct correlation of trust and reciprocity.

\section{f. Confidentiality}

Trust defines and regulates the nature of relationships among individuals and groups (Gefen, 2000). This is commonly observed that the level of trust increases with sharing of information and specially specified personal information, because by sharing sensitive personal information people make themselves more vulnerable Blau (1964) and this increased level of vulnerability can lead to increased level of confidence and trust towards them (Ridings et al., 2002). Additionally, as McAllister (1995) suggests trust decisions in many instances tend to be made based on sharing personal or codified information of individuals with others. By sharing personal confided information, people reduce the extent of strange feelings towards others and create an atmosphere of acquaintance or friendliness (Ridings et al., 2002). Likewise, confidentiality and keeping secrets help in understanding the level of integrity and benevolence and both integrity and benevolence are two of the three fundamental components of trustworthiness (Ridings et al., 2002). Knowing about others makes easy to decide whether to trust someone or not. Sharing of personal information and secrets helps in understanding and judgment process and that helps in trust building (Blau, 1964; Luhmann, 1979). Confidentiality from trustee is also reported by Butler Jr (1999) as a significant factor that facilitates the building of interpersonal trust. H. H. Tan and Chee

Sukkur IBA Journal of Management and Business | Volume 4 No. 1 January - June 2017 @ Sukkur IBA University 
(2005), have also empirically found confidentiality as an important antecedent to trust development in a study conducted in Singapore.

\section{g. Commitment}

Commitment denotes dedication and devotion of trustee towards trustor in working relationship. H. H. Tan and Chee (2005), have found commitment as an important antecedent to trust building. Commitment gives the connotation of fulfilment of promise in Butler Jr (1999) work. Commitment promotes perseverance in interpersonal relationship (Drigotas \& Rusbult, 1992). Literature suggests that commitment fosters a variety of maintenance behaviors including: willingness to sacrifice something for someone Van Lange et al. (1997); accommodating attitude, (Rusbult, Verette, Whitney, Slovik, \& Lipkus, 1991) and disparagement of alternatives, i.e. tendencies that drive away or derogate tempting alternative partners (Miller, 1997). In the study of H. H. Tan and Chee (2005), respondents shared that a trusted person is not the one who only fulfils the promise but, it is one who shows a strong perseverance in honoring his or her words. In this context, a trusted person is expected to commit the words, despite unfavorable and hostile conditions. Built on this, strong sense of commitment is a critical factor in the building of trust among the two parties (H. H. Tan \& Chee, 2005). Rusbult et al. (1991), have also empirically tested the positive relationship of trust building and commitment. Their findings from two longitudinal studies evidenced that commitment stimulated acts like willingness to sacrifice.

\section{h. Loyalty}

Butler Jr and Cantrell (1984), described loyalty as a feeling of compassion, kindness and altruism towards someone or an individual's willingness to support someone and safeguard his or her rights and interests. Jennings (1971), defines loyalty as an implied assurance from one party to remain faithful and not to cause harm to other party. Loyalty has also been discussed in trust literature Jennings (1971) as an antecedent to trust building. However, despite numerous researchers e.g. (Reichheld, Markey Jr, \& Hopton, 2000; Reynolds, 2000) have recurrently highlighted the significance of trust and loyalty. Empirical evidence into this area still needs serious focus and attention of researchers e.g. (Stewart, 2003). (H. H. Tan \& Chee, 2005), found loyalty as a very strong element of trust development in a study conducted in Singapore. In their study, a large number of respondents mentioned loyalty as a very important trustworthiness attribute, especially with respect to boss-subordinate relationship (H. H. Tan \& Chee, 2005). From an organizational perspective, loyalty according to $\mathrm{H}$. H. Tan and Chee (2005) as explained by their respondents in their research, is a single-minded faithfulness towards the organization and management. The influence of loyalty on trust has been extensively discussed in buyer-seller trust based relationship e.g. (Lau \& Lee, 1999). Harris and Goode (2004), in their study regarding buyer and seller relationship have found a positive correlation between trust and loyalty.

Sukkur IBA Journal of Management and Business | Volume 4 No. 1 January - June 2017 @ Sukkur IBA University 


\section{i. Time Spent}

Extant research provides evidence that the proper regularity of one-to-one interaction is an important factor for team effectiveness Maznevski and Chudoba (2000) and therefore, trust building between previously unacquainted members takes longer (Wilson, Straus, \& McEvily, 2006). The importance of time factor is recognized in the discussion of trust building process of Mayer et al. (1995) "as the relationship develops, interactions with the trustee allow the trustor to gain insights about the trustee's benevolence and the relative impact of benevolence on trust will grow". Also integrity is assessed through the consistency of actions over time: "The extent to which the party's actions are congruent with his or her words all affect the degree to which the party is judged to have integrity" (p. 722).

\section{j. Religiosity}

Strong religiosity according to many scholars is also one of the antecedents to trust. Previous studies have proposed that religious beliefs are linked with trust in people (Bègue, 2002). Keeping in view the relationship between religiosity and interpersonal trust, Schoenfeld (1978) observed that attendance in churches fosters a more trusting stance to others. A study of Maddock and Kenny (1972) noted that intrinsically religious individuals generally score higher on the subscale of trustworthiness in connection with Wrightsman (1991) philosophies of human nature scale. Lupfer and Wald (1985), have also suggested that religiously committed people perceive others to be altruistic and truthful. In a study conducted in a French context, Bègue (2002) has empirically proved a positive relationship between religiosity and trustworthiness. In an experimental study by J. H. Tan and Vogel (2008) it is empirically tested that religious people generally tend to be more trustworthy and they generally trust others. In another study conducted by H. H. Tan and Chee (2005) among Japanese and Japanese Americans; religiosity, acculturation and autonomy preference, were strongly related to trust in one's physician.

\section{k. Shared Values}

Shared values are one of the important antecedents of trust building. Shared values can be described as common set of social principles, standards, norms and convictions that channelize behaviors and attitudes of a given society or group. Shared values unite dissociated people to a collective platform and allow them to communicate with each other and promote their feelings and ideas in a combined manner (Wu, Chen, \& Chung, 2010). Indeed, shared values guide to the development of homogenous communication channels and behavioral manifestations that infuse a sense of attachment and belonging among the individuals (Morgan \& Hunt, 1994). Formulation and reinforcement of shared goals is critical for gaining common understanding and discouraging opportunism which is very important for building trust. Numerous research studies have identified shared values being important antecedent of social trust (Cazier et al., 2006). Morgan and Hunt (1994), for instance, found that shared values foster mutual trust through simplifying communication and cooperation among group members. Cazier et

Sukkur IBA Journal of Management and Business | Volume 4 No. 1 January - June 2017 @ Sukkur IBA University 
al. (2006), also established that shared goals considerably influence individuals' degree of trust towards their colleagues.

\section{Organizational Justice}

Perceived impartiality of organizational reward systems, simply, the organizational justice, may facilitate trust building among employees of an organization (Bartol \& Srivastava, 2002). Organizational justice is a term used to delineate the presence and influence of fairness at work place Greenberg (2005) and it includes both procedural and distributive dimensions. Procedural justice relates to the perception of employees regarding the application of fairness in their job duties and other aspects of their work; like work-place tools and work environment Yusof and Shamsuri (2006) and distributive justice according to Price (1997), addresses the issues of fairness in compensation and rewarding of employees in return to their performance and contribution. Bartol and Srivastava (2002), suggest that both types of justice will affect the degree of trust among workers and at workplaces. Many research studies empirically evidenced positive relationship between organizational justice and trust at workplaces (Lance Frazier, Johnson, Gavin, Gooty, \& Bradley Snow, 2010). This is natural that employees always compare their workload and compensation with their colleagues and if they feel any unfairness, it disturbs their relationship, creating personal grudges and conflicts which are detrimental for trust building. That is why, Leventhal (1976) emphasized that managers while allocating organizational incentives and rewards need to be fair and trustworthy and ensure impartiality, because it will be a critical element of building trusting atmosphere within organizations.

\section{Discussion and Implications for Managers}

The objective of this paper was to suggest a research agenda for the analysis of antecedents to interpersonal trust development from organizational perspective. The study found that trustworthiness, propensity to trust, affect, social group membership, confidentiality, commitment, loyalty all are important for the development of interpersonal trust. Additionally, shared values, organizational justice, religiosity, confidentiality and time orientation are also significant for the cultivation of interpersonal trust. Keeping in view the importance of trust, managers should try to develop appropriate mechanisms that may improve the quality of interpersonal relationships among members characterized by mutual trust and cooperation. This means that the HR managers should try to ensure and increase the level of interpersonal trust among organizational members and make efforts to create a culture of mutual trustworthiness within the organizations, founded on social interaction ties and a vision for collaborative effort for superior organizational functioning. For achieving this goal, they need to understand the perceptions of their employees regarding the factors, which increase or decrease the level of interpersonal trust and then try to promote traits and behaviors that lead towards building and enhancing the level of trust and discourage those trends and traits that deter interpersonal trust. Additionally, managers can create better trust-based relations among employees through facilitating the norms of

Sukkur IBA Journal of Management and Business | Volume 4 No. 1 January - June 2017 @ Sukkur IBA University 
confidentiality, commitment, loyalty, confidentiality. Moreover, the managers need to promote an environment of cooperation, shared vision and open communication among the employees backed by organizational justice and fairness with regard to distribution of organizational resources, awarding of organizational rewards and assigning of duties, since feelings of unfairness and injustice create conflicts and shatter the confidence and trust. Prior literature maintains that structural ties could be strengthened through frequent social interactions, which may cultivate a shared vision through hands-on experience over time (Wasko \& Faraj, 2005). Despite a plethora of research being conducted in the discipline of trust in the past two decades, every new research study only indicates that a lot more needs to be conducted to investigate and analyses some new very promising dimensions and avenues of this extremely important construct.

\section{References}

Akbar, E., Saeed, S., Mehdi, A., \& Saeed. (2010). A.Importance of the Relationship between Psychological Empowerment of Employees and Human Resources Productivity In Government Organizations. European Journal of Economics and Finance, 26(13), 44-56.

Arrow, K. (1974). The limits of organization.

Barney, J. B., \& Hansen, M. H. (1994). Trustworthiness as a source of competitive advantage. Strategic management journal, 15(S1), 175-190.

Bartol, K. M., \& Srivastava, A. (2002). Encouraging knowledge sharing: The role of organizational reward systems. Journal of Leadership \& Organizational Studies, 9(1), 64-76.

Bashyakar, M., Mohandas, J. (2010). Building Trust Among Employees. Global Management Review, 4(2), 27-32.

Bègue, L. (2002). Beliefs in justice and faith in people: Just world, religiosity and interpersonal trust. Personality and Individual Differences, 32(3), 375-382.

Berg, J., Dickhaut, J., \& McCabe, K. (1995). Trust, reciprocity, and social history. Games and economic behavior, 10(1), 122-142.

Blau, P. M. (1964). Exchange and power in social life: Transaction Publishers.

Brewer, M. B. (1979). In-group bias in the minimal intergroup situation: A cognitivemotivational analysis. Psychological bulletin, 86(2), 307.

Brewer, M. B., \& Brown, R. J. (1998). Intergroup relations: McGraw-Hill.

Buchan, N. R., Croson, R. T., \& Dawes, R. M. (2002). Swift neighbors and persistent strangers: A cross-cultural investigation of trust and reciprocity in social exchange. American Journal of Sociology, 108(1), 168-206.

Butler Jr, J. K. (1999). Trust expectations, information sharing, climate of trust, and negotiation effectiveness and efficiency. Group \& Organization Management, 24(2), 217-238.

Sukkur IBA Journal of Management and Business | Volume 4 No. 1 January - June 2017 @ Sukkur IBA University 
Butler Jr, J. K., \& Cantrell, R. S. (1984). A behavioral decision theory approach to modeling dyadic trust in superiors and subordinates. Psychological reports, 55(1), 19-28.

Cazier, J. A., Shao, B. B., \& Louis, R. D. S. (2006). E-business differentiation through value-based trust. Information \& Management, 43(6), 718-727.

Costa, A. C., Roe, R. A., \& Taillieu, T. C. B. (2001). Trust implications for performance and effectiveness. European Journal of Work \& Organizational Psychology, 10(3), 225-244.

Das, T. K., \& Teng, B.-S. (1998). Between trust and control: Developing confidence in partner cooperation in alliances. Academy of management review, 23(3), 491512.

DeNeve, K. M., \& Cooper, H. (1998). The happy personality: a meta-analysis of 137 personality traits and subjective well-being. Psychological bulletin, 124(2), 197.

Dirks, K. T. (2000). Trust in leadership and team performance: Evidence from NCAA basketball. Journal of applied psychology, 85(6), 1004.

Dirks, K. T., \& Ferrin, D. L. (2002). Trust in leadership: meta-analytic findings and implications for research and practice: American Psychological Association.

Drigotas, S. M., \& Rusbult, C. E. (1992). Should I stay or should I go? A dependence model of breakups. Journal of Personality and Social Psychology, 62(1), 62.

Geanakoplos, J., Pearce, D., \& Stacchetti, E. (1989). Psychological games and sequential rationality. Games and economic behavior, 1(1), 60-79.

Gefen, D. (2000). E-commerce: the role of familiarity and trust. Omega, 28(6), 725737.

Gill, H., Boies, K., Finegan, J. E., \& McNally, J. (2005). Antecedents of trust: Establishing a boundary condition for the relation between propensity to trust and intention to trust. Journal of business and psychology, 19(3), 287-302.

Greenberg, J. (2005). Managing behavior in organizations: Prentice Hall.

Gulati, R. (1995). Does familiarity breed trust? The implications of repeated ties for contractual choice in alliances. Academy of management journal, 38(1), 85112.

Hardin, R. (2002). Trust and trustworthiness: Russell Sage Foundation.

Harris, L. C., \& Goode, M. M. (2004). The four levels of loyalty and the pivotal role of trust: a study of online service dynamics. Journal of retailing, 80(2), 139-158.

Hilton, J. L., \& Von Hippel, W. (1996). Stereotypes. Annual review of psychology, 47(1), 237-271.

Inkpen, A. C., \& Currall, S. C. (1997). International joint venture trust: An empirical examination: New Lexington Press.

Jennings, E. E. (1971). Routes to the executive suite.

Katinka, B., \& Paul, K. (2003). Introduction: trust within organisations. Personnel Review, 32(5), 543-555.

Sukkur IBA Journal of Management and Business | Volume 4 No. 1 January - June 2017 @ Sukkur IBA University 
Kramer, R. M. (1999). Trust and distrust in organizations: Emerging perspectives, enduring questions. Annual review of psychology, 50(1), 569-598.

Kramer, R. M., \& Brewer, M. B. (1984). Effects of group identity on resource use in a simulated commons dilemma. Journal of Personality and Social Psychology, 46(5), 1044.

Lance Frazier, M., Johnson, P. D., Gavin, M., Gooty, J., \& Bradley Snow, D. (2010). Organizational justice, trustworthiness, and trust: A multifoci examination. Group \& Organization Management, 35(1), 39-76.

Lau, G. T., \& Lee, S. H. (1999). Consumers' trust in a brand and the link to brand loyalty. Journal of Market-Focused Management, 4(4), 341-370.

Leventhal, G. S. (1976). The distribution of rewards and resources in groups and organizations. Advances in experimental social psychology, 9, 91-131.

Levin, D. Z., \& Cross, R. (2004). The strength of weak ties you can trust: The mediating role of trust in effective knowledge transfer. Management science, 50(11), 1477-1490.

Lewicki, R. J., \& Bunker, B. B. (1996). Developing and maintaining trust in work relationships. Trust in organizations: Frontiers of theory and research, 114, 139.

Luhmann, N. (1979). Trust and power. 1979. John Willey \& Sons.

Luo, Y. (2002). Building trust in cross-cultural collaborations: Toward a contingency perspective. Journal of management, 28(5), 669-694.

Lupfer, M., \& Wald, K. (1985). An exploration of adults' religious orientations and their philosophies of human nature. Journal for the Scientific Study of Religion, 293304.

Maddock, R. C., \& Kenny, C. T. (1972). Philosophies of human nature and personal religious orientation. Journal for the Scientific Study of Religion, 277-281.

Madhok, A. (2006). Revisiting multinational firms' tolerance for joint ventures: A trustbased approach. Journal of international Business studies, 37(1), 30-43.

Mayer, R. C., Davis, J. H., \& Schoorman, F. D. (1995). An integrative model of organizational trust. Academy of management review, 20(3), 709-734.

Maznevski, M. L., \& Chudoba, K. M. (2000). Bridging space over time: Global virtual team dynamics and effectiveness. Organization science, 11(5), 473-492.

McAllister, D. J. (1995). Affect-and cognition-based trust as foundations for interpersonal cooperation in organizations. Academy of management journal, 38(1), 24-59.

McEvily, B., Perrone, V., \& Zaheer, A. (2003). Trust as an organizing principle. Organization science, 14(1), 91-103.

Miller, R. S. (1997). Inattentive and contented: Relationship commitment and attention to alternatives. Journal of Personality and Social Psychology, 73(4), 758.

Mishra, A. K. (1996). Organizational responses to crisis. Trust in organizations: Frontiers of theory and research, 261. 
M. A. Basit-M. et al. / A Research Framework for Antecedents to Interpersonal Trust Development from

Morgan, R. M., \& Hunt, S. D. (1994). The commitment-trust theory of relationship marketing. The journal of marketing, 20-38.

Price, J. L. (1997). Handbook of organizational measurement. International journal of manpower, 18(4/5/6), 305-558.

Putnam, R. D. (2001). Bowling alone: The collapse and revival of American community: Simon and Schuster.

Reichheld, F. F., Markey Jr, R. G., \& Hopton, C. (2000). E-customer loyalty-applying the traditional rules of business for online success. European Business Journal, 12(4), 173.

Rempel, J. K., Holmes, J. G., \& Zanna, M. P. (1985). Trust in close relationships. Journal of Personality and Social Psychology, 49(1), 95.

Reynolds, J. (2000). eCommerce: a critical review. International Journal of Retail \& Distribution Management, 28(10), 417-444.

Ridings, C. M., Gefen, D., \& Arinze, B. (2002). Some antecedents and effects of trust in virtual communities. The Journal of Strategic Information Systems, 11(3), 271-295.

Rusbult, C. E., Verette, J., Whitney, G. A., Slovik, L. F., \& Lipkus, I. (1991). Accommodation processes in close relationships: Theory and preliminary empirical evidence. Journal of Personality and Social Psychology, 60(1), 53.

Schoenfeld, E. (1978). Image of man: The effect of religion on trust: A research note. Review of Religious Research, 61-67.

Schoorman, F. D., Mayer, R. C., \& Davis, J. H. (2007). An integrative model of organizational trust: Past, present, and future. Academy of management review, 32(2), 344-354.

Shaw, J. (2001). Management training in eastern Europe and the implication for educational change in a changing context. Learning and Teaching Responsibility, Business Studies Department, London Guildhall University, $U K$.

Smith, K. G., Carroll, S. J., \& Ashford, S. J. (1995). Intra-and interorganizational cooperation: Toward a research agenda. Academy of management journal, $38(1), 7-23$.

Stewart, K. J. (2003). Trust transfer on the world wide web. Organization science, 14(1), 5-17.

Tajfel, H., \& Turner, J. (1986). The social identity theory of inter group behavior in S Worchel \& WG Austin (Eds) Psychology of intergroup relations. Chicago: Nelson.

Tan, H. H., \& Chee, D. (2005). Understanding interpersonal trust in a Confucianinfluenced society: An exploratory study. International Journal of Cross Cultural Management, 5(2), 197-212.

Tan, J. H., \& Vogel, C. (2008). Religion and trust: An experimental study. Journal of Economic Psychology, 29(6), 832-848. 
M. A. Basit-M. et al. / A Research Framework for Antecedents to Interpersonal Trust Development from

Turner, J. C., Hogg, M. A., Oakes, P. J., Reicher, S. D., \& Wetherell, M. S. (1987). Rediscovering the social group: A self-categorization theory: Basil Blackwell.

Van Lange, P. A., Rusbult, C. E., Drigotas, S. M., Arriaga, X. B., Witcher, B. S., \& Cox, C. L. (1997). Willingness to sacrifice in close relationships. Journal of Personality and Social Psychology, 72(6), 1373.

Wasko, M. M., \& Faraj, S. (2005). Why should I share? Examining social capital and knowledge contribution in electronic networks of practice. MIS quarterly, 3557.

Wasti, S. A., Tan, H. H., \& Erdil, S. E. (2011). Antecedents of trust across foci: A comparative study of Turkey and China. Management and Organization Review, 7(2), 279-302.

Williams, M. (2001). In whom we trust: Group membership as an affective context for trust development. Academy of management review, 26(3), 377-396.

Williamson, O. E. (1993). Calculativeness, trust, and economic organization. The Journal of Law and Economics, 36(1, Part 2), 453-486.

Wilson, J. M., Straus, S. G., \& McEvily, B. (2006). All in due time: The development of trust in computer-mediated and face-to-face teams. Organizational behavior and human decision processes, 99(1), 16-33.

Wrightsman, L. S. (1991). Interpersonal trust and attitudes toward human nature.

Wu, J.-J., Chen, Y.-H., \& Chung, Y.-S. (2010). Trust factors influencing virtual community members: A study of transaction communities. Journal of Business Research, 63(9), 1025-1032.

Yusof, A., \& Shamsuri, N. (2006). Organizational justice as a determinant of job satisfaction and organizational commitment. Malaysian Management Review, 41(1), 47-62.

Zaheer, A., McEvily, B., \& Perrone, V. (1998). Does trust matter? Exploring the effects of interorganizational and interpersonal trust on performance. Organization science, 9(2), 141-159.

Zak, P. J., \& Knack, S. (2001). Trust and growth. The economic journal, 111(470), 295321.

Zand, D. E. (1972). Trust and managerial problem solving. Administrative science quarterly, 229-239.

Zolin, R., Hinds, P. J., Fruchter, R., \& Levitt, R. E. (2004). Interpersonal trust in crossfunctional, geographically distributed work: A longitudinal study. Information and organization, 14(1), 1-26.

Zucker, L. G. (1986). Production of trust: Institutional sources of economic structure, 1840-1920. Research in organizational behavior. 